\title{
血栓症患者における凝固線溶系と血栓溶解療法の検討
}

\begin{tabular}{|c|c|c|c|c|}
\hline 晴男* & Alam & Shafiqul* & 森口 & 宮 \\
\hline 輝男* & 矢野 & 孝* & 塩野谷恵彦* & 伴 \\
\hline
\end{tabular}

\section{Studies on coagulation and fibrinolysis in patients with thrombosis and thrombolytic therapy}

\author{
Haruo SATOH*, Shafiqul ALAM*, Susumu MORIGUCHI*, \\ Masayuki MIYAUCHI*, Teruo IKEZAWA*, Takashi YANO*, \\ Shigehiko SHIONOYA* and Ichiro BAN**
}
Key words: Buerger's disease, arteriosclerosis obliterans, acute arterial thrombosis, acute deep venous thrombosis, thrombolytic therapy (urokinase, tissue type plasminogen activator)

Coagulation and fibrinolysis were studied in normal subjects and patients with Buerger's disease (TAO), arteriosclerosis obliterans (ASO), acute arterial thrombosis (AAT) and acute deep venous thrombosis (ADVT); the mean ages were $32.8,42,5,63.5,64.8$ and 60.2 years respectively. $\beta$-TG significantly elevated in all the patient groups compared with the normal subjects. FPA, FPB $\beta$ 15-42 and D-dimer significantly elevated in ASO, AAT and ADVT groups compared with the normal subjects and TAO groups. Therefore in ASO, AAT and ADVT groups, there might be platelet activation, hypercoagulability and increased fibrinolysis, whereas TAO group seemed to have only platelet activation. These results might be dependent on difference in the amount of unorganized thrombi among the patient groups. Low activity of $\alpha_{2}$-PI showed effective fibrinolysis in thrombolytic therapy (urokinase and t-PA) by means of ultiple regression analysis. Using fibrin plate method, fibrinolysis area appeared when $\alpha_{2}$-PI was less than $50 \%$ in urokinase therapy. Judging from the measurement of $\alpha_{2}$-PI after administration of urokinase, it was expected that $\alpha_{2}$-PI was almost maintained below $50 \%$ when 600,000 units of urokinase were intravenously infused for 3

* 名古屋大学医学部第一外科 [干 466 名古屋市昭和区鶴舞町 65], First Department of Surgery, Nagoya University of Medicine, Nagoya, Japan.

** 名古屋大学医療技術短期大学部, Nagoya University College of Medical Technology, Nagoya, Japan. 受付: 1988. 1. 7. 受理 : 1988. 7. 12 . 
hours on the first day and an intravenous administration of 300,000 units of urokinase for 1. 5 hours were given daily from the following day.

\section{I. 目 的}

バージャ一病 (TAO) と閉塞性 動脈硬化症 （ASO）では急性動脈閉塞をきたすことがある ので, TAO, ASO, 急性動脈閉塞症 (AAT), 急性深部静脈血栓症 (ADVT) の凝固線溶系と 血栓溶解療法について比較検討した。

\section{II. 対象および方法}

健常者 18 名, TAO 20 名, ASO 33 名, グ ラフト閉塞の 9 名を含む AAT 19名, ADVT 8 名を対象とした。凝固線溶系に影響する薬剤 の使用症例㘧よび DIC，肝疾患，腎疾患，心 疾患, 脳血管障害症例を除いた。健常者, TAO, ASO, AAT, ADVT の平均年秢はそれぞれ $32.8 ， 42.5,63.5,64.8,60.2$ 歳であった。 $\beta$-TG, FPA, FPB $\beta$ 15-42 (FPB $\beta), \quad D$-dimer (DD), $\mathrm{t}-\mathrm{PA}$ 抗原量, protein $\mathrm{C}$ 抗原量 $(\mathrm{P}$ C), fibrinogen (fg), plasminogen (pg), AT III 活性, $\alpha_{2}-\mathrm{PI}$ 活性, PT, APTT を測定し た。た TAO 3 名, ASO 4 名, AAT 3 名
に urokinase (UK) 60 万単位を 3 時間で点滴 静中し, 投与量, 投与方法について検討した. グラフト閉塞の 3 例を含む AAT 6 名, ADVT 2 名に $\mathrm{t}-\mathrm{PA}$ を点滴静中し凝固線溶系の変動を みた。

\section{III. 成績および考察}

表 1 亿各測定項目の成績を示した。 $\beta$-TG の 成績から TAO, ASO, AAT, ADVT は健常 者に比べ有意に高値を示し, 血小板機能充進状 態を示した。 FPA，FPB $\beta$ からみると，ASO， AAT, ADVT は健常者, TAO に比べ有意に 高値を示し, 凝固線溶六進状態と考えられた。 DD の成績から, ASO, AAT, ADVT は健常 者, TAO に比べ有意に高值を示し, さらに AAT, ADVT は ASO に比べ有意に高值を示 した。これから ASO, AAT, ADVTでは血栓 溶解量が多いと思われ, AAT, ADVT では最 も多い結果を示した ${ }^{1)}$. t-PA 抗原量は急性動 脈閉塞症に拈いて一過性に増加した。 UK 60 万単位を点滴静中したとき $\mathrm{FPB} \beta$ を目的変数,

Table 1 Coagulation and fibrinolysis in normal subject and patients with TAO, ASO, AAT,ADVT

\begin{tabular}{|c|c|c|c|c|c|c|}
\hline & & normal & TAO & ASO & $\mathrm{AAT}$ & ADVT \\
\hline$\beta-\mathrm{TG}$ & $(\mathrm{ng} / \mathrm{m} l)$ & $21.4 \pm 12.0$ & $34.1 \pm 19.2^{*}$ & $36.6 \pm 20.3^{* *}$ & $38.1 \pm 16.1^{* *}$ & $50.5 \pm 31.9 *$ \\
\hline FPA & $(\mathrm{ng} / \mathrm{m} l)$ & $1.5 \pm 1.2$ & $1.9 \pm 2.2$ & $9.8 \pm 17.5^{* \dagger}$ & $28.5 \pm 34.8^{* \dagger}$ & $29.1 \pm 25.0^{* \dagger}$ \\
\hline $\mathrm{FPB} \beta$ & $(\mathrm{ng} / \mathrm{m} l)$ & $7.6 \pm 4.0$ & $7.6 \pm 3.9$ & $10.8 \pm 4.9^{* \dagger}$ & $15.3 \pm 11.9 * \dagger$ & $20.7 \pm 8.8^{* *+\dagger}$ \\
\hline DD & $(\mathrm{ng} / \mathrm{m} l)$ & $66.1 \pm 18.5$ & $75.1 \pm 29.1$ & 153. $3 \pm 69.0^{* *+\dagger}$ & $730.5 \pm 691.2^{* * \dagger \dagger * \#}$ & $985.3 \pm 740.2^{* \dagger *}$ \\
\hline $\mathrm{t}-\mathrm{PA}$ & $(\mathrm{ng} / \mathrm{m} l)$ & $2.4 \pm 1.1$ & $2.7 \pm 1.3$ & $2.8 \pm 1.2$ & $4.5 \pm 1.7^{* *+\dagger * *}$ & $5.8 \pm 5.5$ \\
\hline $\mathrm{P}-\mathrm{C}$ & $(\mathrm{ng} / \mathrm{m} l)$ & $111.5 \pm 23.4$ & $125.3 \pm 15.4$ & $106.8 \pm 22.0 \dagger \dagger$ & $98.5 \pm 26.8^{\dagger \dagger}$ & $113.7 \pm 33.1$ \\
\hline $\mathrm{fg}$ & $(\mathrm{mg} / \mathrm{d} l)$ & $(300 \pm 100)$ & $321.1 \pm 107.2$ & $359.3 \pm 97.2$ & $311.0 \pm 46.7$ & $313.6 \pm 92.1$ \\
\hline pg & $(\%)$ & $(100 \pm 20)$ & $101.6 \pm 13.5$ & $95.2 \pm 15.5$ & $88.0 \pm 15.1$ & $97.1 \pm 18.0^{\dagger}$ \\
\hline$\alpha_{2}-\mathrm{PI}$ & $(\%)$ & $(100 \pm 20)$ & $103.8 \pm 10.1$ & $93.7 \pm 14.1 \dagger$ & $94.4 \pm 18.9$ & $90.4 \pm 21.0$ \\
\hline AT III & $(\%)$ & $(100 \pm 20)$ & $112.6 \pm 13.1$ & $104.0 \pm 16.1$ & $95.1 \pm 17.0 \dagger \dagger$ & $95.9 \pm 14.0 \dagger$ \\
\hline PT & $(\%)$ & $(100 \pm 20)$ & $101.9 \pm 16.7$ & $94.4 \pm 14.7$ & $89.3 \pm 31.9$ & $68.9 \pm 7.3+\uparrow \#$ \\
\hline APTT & $(\%)$ & $(100 \pm 20)$ & $108.2 \pm 32.4$ & $111.2 \pm 42.5$ & $83.7 \pm 36.2 \dagger^{\dagger}$ & $90.2 \pm 24.0$ \\
\hline
\end{tabular}

all data present mean \pm S.D.

$* \mathrm{p}<0.05$, ** $\mathrm{p}<0.01$ compared with normal subject group

$\dagger \mathrm{p}<0.05,+\dagger \mathrm{p}<0.01$ compared with TAO group

* $\mathrm{p}<0.05$, * $\mathrm{p}<0.01$ compared with ASO group 


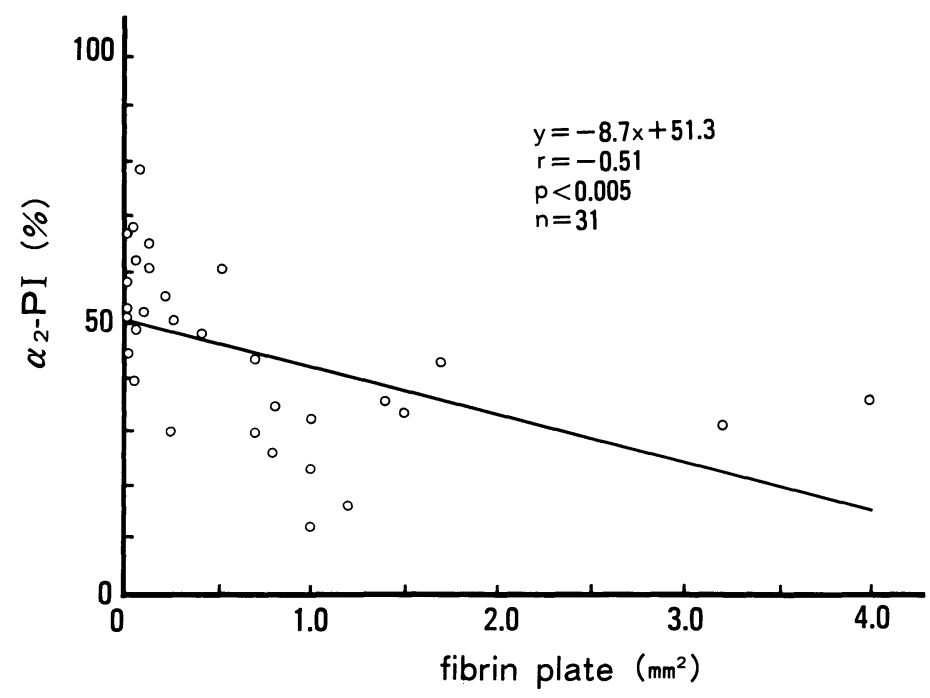

Fig. 1 Correlation between lysis area on fibrin plates and $\alpha_{2}$-PI during urokinase administration.

$\alpha_{2}-\mathrm{PI}$ 活性, pg を説明変数として線形重回帰 モデル22を作製すると $[\mathrm{FPB} \beta]=346.4-11.2$ $\left[\alpha_{2}-\mathrm{PI}\right]+7.8[\mathrm{pg}]$ であらわされ有意となった. 標準回帰係数は $\alpha_{2}-\mathrm{PI}, \mathrm{pg}$ の順に-0.76, 0.34 となった。 また t-PAを 30 分から 3 時間 点滴静中したとき $\mathrm{FPB} \beta$ を目的変数， $\alpha_{2}-\mathrm{PI}$ 活 性, $\mathrm{t}-\mathrm{PA}$ 抗原量を説明変数として線形重回㷌モ デルを作製すると $[\mathrm{FPB} \beta]=49.75-0.42\left[\alpha_{2}-\right.$ $\mathrm{PI}]+0.07$ [t-PA] であらわされ有意となった。 標準回帰係数は $\alpha_{2}-\mathrm{PI}, \mathrm{t}-\mathrm{PA}$ の順に-0.58, 0.36 となった。 いずれにおいても $\alpha_{2}-\mathrm{PI}$ の関 与が大きいことを示した。 Mimuro ら ${ }^{3)}$ の血中 の $\alpha_{2}-\mathrm{PI}$ を低く保つと血栓中の $\alpha_{2}-\mathrm{PI}$ が低く なり血栓溶解につながるといら報告，Kumada ら ${ }^{4)}$ の $\alpha_{2}$-PI の抗体を用いた動物実験で， $\alpha_{2}-$ PI を 50 \%以下に保った場合血栓は control に 比べ有意に溶解したという報告はこの裏付けに なると思われる。な拉 AAT 例では UK 投与 時 $\mathrm{FPB} \beta$ と DD とは相関がみられた。図 1 に UK 投与時の $\alpha_{2}-\mathrm{PI}$ と fibrin plate (FibrinPlate, 北里研究所製) の溶解面積との関係を示 した。これから $\alpha_{2}$-PI がほぼ $50 \%$ 以下の時 fibrin plate に溶解がみられた。 UK 60 万単位 を 3 時間で投与したとき $\alpha_{2}-\mathrm{PI}$ は 3 時間後に
は $30.2 \%$ に達し 21 時間後には $61.2 \%$ に回復 した。 $\alpha_{2}-\mathrm{PI}$ が $50 \%$ に達するのに 1.6 時間要 し，UK の総投与量は 32.2 万単位となった。 したがって UK を初回 60 万単位を 3 時間で, 翌日から 30 万単を 1.5 時間で投与すれば $\alpha-\mathrm{PI}$ をほぼ50\%以下に保つことが可能である，少 なくとも UK の投与量はこの程度必要と考兄 られた。

\section{IV. 結 語}

(1) $\beta$-TG, FPA，FPB $\beta$ の成績から TAO に は血小板機能充進状態, ASO, AAT, ADVT には血小板機能と凝固線溶充進状態の存在が示 唆された。

（2）血栓溶解療法（UK， t-PA）においては $\alpha_{2}$-PI を低值に保つことが重要であり，UK 療 法に際しては初日 60 万単位, 翌日から 30 万単 位投与すれば $\alpha_{2}-\mathrm{PI}$ 活性をほぼ $50 \%$ 以下に保 つことが可能である.

\section{文献}

1）佐藤晴男, 他 : バージャ一病, 閉塞性動脈硬化 症, 胸部扣よび腹部大動脈瘤飞括ける凝固線溶 系の検討，血液と脈管，18：367～369，1987.

2) 田中 豊, 他：パソコン統計解析ハンドブック 
II 多変量解析編. 共立出版, 東京, pp $1 \sim 70$, 1984.

3) Mimuro, J., et al.: Release of $\alpha_{2}$-plasmin inhibitor from plasma fibrin clots by activated coagulation factor XIII. J. Clin. Invest., 77:
1006 1013, 1986.

4) Kumada, T., et al.: Physiological role of $\alpha_{2}$-plasmin inhibitor in rats. Thromb. Res., 36: $153 \sim 163,1984$. 